\title{
SPINE TRAUMA EPIDEMIOLOGICAL PROFILE IN A TERTIARY NEUROSURGERY HOSPITAL IN SOUTH BRAZIL
}

\author{
PERFIL EPIDEMIOLÓGICO DE TRAUMA RAQUIMEDULAR EM HOSPITAL NEUROCIRÚRGICO \\ TERCIÁRIO NO SUL DO BRASIL
}

\section{PERFIL EPIDEMIOLÓGICO DE TRAUMA RAQUIMEDULAR EN HOSPITAL NEUROQUIRÚRGICO TERCIARIO EN EL SUR DE BRASIL}

Guilherme Finger ${ }^{1}$, Tiago Paczko Bozko Cecchinl² ${ }^{2}$, Maria Eduarda Conte Gripa², Tobias ludwig do Nascimento ${ }^{1}$, Felipe Martins de Lima Cecchinl,

Ericson Sfredo ${ }^{1}$, André Martins de Lima Cecchinn ${ }^{1}$, Asdrubal Falavigna ${ }^{3}$

1. Hospital Cristo Redentor, Neurosurgery Department, Porto Alegre, RS, Brazil.

2. Universidade Luterana do Brasil, Canoas, RS, Brazil.

3. Universidade de Caxias do Sul, Department of Neurosurgery, Caxias do Sul, RS, Brazil.

\begin{abstract}
Objective: The aim of this paper is to analyze the epidemiological profile of a large series of spine trauma victims in the Southernmost state of Brazil. Methods: A retrospective study including spine trauma patients was performed at a tertiary hospital from January 1 st, 2013 to December 31st, 2018. The variables analyzed include demographic data, information related to the trauma (etiology, trauma mechanism, type of spine injury, number of vertebrae involved, vertebral segment involved), neurological status at hospital admission (Frankel scale), treatment performed and the outcome (number of days in hospital, neurological outcome, and mortality). Results: A total of 808 patients were included. The mean age was 47.9 ( \pm 19.0$)$, and the majority were male and Caucasian. The most frequent etiology was falls from height $(\mathrm{N}=508 ; 62.9 \%)$ followed by traffic accidents $(\mathrm{N}=185 ; 22.9 \%)$. The thoracolumbar segment was the spinal segment most frequently affected, occurring in 401 (52.1\%) patients, followed by the cervical, thoracic and lumbar segments. The incidence of SCI was 16.7\%. Non-operative treatment was indicated in 510 (63.1\%) patients. Conclusion: The authors presented the largest epidemiological profile regarding spine trauma in Latin America, analyzing a total of 808 patients, which represents an incidence of 134.6 cases/year. This paper fills a gap in the medical literature regarding the epidemiological profile of this disease in Latin America. Level of evidence II; Prognostic study.
\end{abstract}

Keywords: Spinal Cord Injuries; Spinal Fractures, Fractures, Bone; Epidemiology.

\section{RESUMO}

Objetivos: O objetivo deste artigo é analisar o perfil epidemiológico, com base em uma grande série de pacientes acometidos por trauma raquimedular no extremo sul do Brasil. Métodos: Estudo retrospectivo que incluiu pacientes com trauma raquimedular realizado em um hospital terciário entre $1^{\circ}$ de janeiro de 2013 e 31 de dezembro de 2018. As variáveis analisadas incluem dados demográficos, informações referentes ao trauma (etiologia, mecanismo, tipo de lesão, número de vértebras envolvidas e segmento vertebral afetado), estado neurológico à internação (escala de Frankel), tratamento realizado e desfecho (dias de internação, resultado neurológico e mortalidade). Resultados: Um total de 808 pacientes foram incluídos. A média de idade do grupo foi de 47,9 ( \pm 19,0), sendo a maioria do sexo masculino e caucasiana. A etiologia mais frequente foi queda de altura $(N=508 ; 62,9 \%)$ seguida de acidentes de trânsito ( $N=185$; 22,9\%). O segmento toracolombar foi o mais acometido, ocorrendo em 401 (52,1\%) pacientes, seguido pelo cervical, torácico e lombar. A incidência de lesão raquimedular foi de 16,7\%. O tratamento não cirúrgico foi indicado para 510 (63,1\%) pacientes. Conclusão: Os autores apresentam o maior perfil epidemiológico de trauma de coluna da América Latina, analisando um total de 808 pacientes, o que representa uma incidência de 134,6 casos / ano. Este artigo preenche uma lacuna da literatura médica no que diz respeito ao perfil epidemiológico desta doença na América Latina. Nível de evidência II; Estudo Prognóstico.

Descritores: Traumatismos da Medula Espinal; Fraturas da Coluna Vertebral; Fraturas Ósseas; Epidemiologia.

\section{RESUMEN}

Objetivos: El objetivo de este artículo es analizar el perfil epidemiológico, con base en una gran serie de pacientes acometidos por trauma raquimedular en el extremo sur de Brasil. Métodos: Estudio retrospectivo que incluyó a pacientes con trauma raquimedular realizado en un hospital terciario entre el 1 de enero de 2013 y el 31 de diciembre de 2018. Las variables analizadas incluyen datos demográficos, informaciones referentes al trauma (etiología, mecanismo, tipo de lesión, número de vértebras involucradas y segmento vertebral afectado), estado neurológico para el internamiento (escala de Frankel), tratamiento realizado y resultados (días de internamiento, resultado neurológico y mortalidad). Resultados: Fue incluido un total de 808 pacientes. El promedio de edad del grupo fue de 47,9 ( $\pm 19,0)$, siendo la mayoría del sexo masculino y caucásico. La etiología más frecuente fue caída de altura ( $N=508 ; 62,9 \%)$ seguida de accidentes de tránsito ( $N=185 ; 22,9 \%)$.

Study conducted at the Neurosurgery Department of Hospital Cristo Redentor, Porto Alegre, RS, Brazil.

Correspondence: Guilherme Finger. Domingos Rubbo St, 20, Porto Alegre, RS, Brazil. 91040-000. guilhermefingermd@gmail.com 
El segmento toracolumbar fue el más acometido, ocurriendo en $401(52,1 \%)$ pacientes, seguido por el cervical, torácico y lumbar. La incidencia de lesión raquimedular fue de 16,7\%. El tratamiento no quirúrgico fue indicado para 510 (63,1\%) pacientes. Conclusión: Los autores presentan el mayor perfil epidemiológico de trauma de columna de América Latina, analizando un total de 808 pacientes, lo que representa una incidencia de 134,6 casos/año. Este artículo llena un vacío de la literatura médica en lo que se refiere al perfil epidemiológico de esta enfermedad en América Latina. Nivel de evidencia II; Estudio Pronóstico.

Descriptores: Traumatismos de la Médula Espinal; Fracturas de la Columna Vertebral; Fracturas Óseas; Epidemiología.

\section{INTRODUCTION}

Spine trauma is defined as any traumatic lesion to the spine secondary to an external etiology, ${ }^{1,2}$ which may be associated with spinal cord injury $(\mathrm{SCl}){ }^{3}$ Spine trauma patients have a high rate of morbidity and when there is associated $\mathrm{SCl}$, most patients have motor, sensitive, and autonomic impairment. ${ }^{4-6}$ Men are three to four times more likely to be affected than women, corresponding to $76-88 \%$ of patients, with a peak age of between 34 and 58 years. ${ }^{7-9}$

Incidence of spine trauma and $\mathrm{SCl}$ varies around the world, with markedly different statistics between developing and non-developed countries. ${ }^{10,11}$ In Asia Pacific, Taiwan has the highest rate, with 40.2 patients per million people with spine trauma, ${ }^{12}$ followed by China and Saudi Arabia, which have rates of 23.7 and 38 patients per million people, respectively. ${ }^{13-15}$ The incidence in the United States varies from 25 to 59 patients per million, with a national average of 40 cases per million people. ${ }^{16-18}$ The incidence is lower in Europe, varying from 10 to 19 cases per million people in countries such as Denmark, Germany, France, Turkey and Sweden. Portugal has the highest rate of spinal trauma cases (58 per million people) when compared to the other European countries..$^{9,13,19-23}$ A systematic review published in 2013 reported the worldwide publications on spine trauma. However, no experience from Latin America was reported. ${ }^{17}$

The incidence of spine trauma in different regions of Brazil see$\mathrm{ms}$ to indicate an approximate incidence of 21 cases per million people. ${ }^{7,10}$ The Brazilian data had small samples and lacked essential epidemiological information. The objective of this study is to analyze the epidemiological profile of patients with spine trauma and $\mathrm{SCl}$ in Rio Grande do Sul, the Southernmost state of Brazil.

\section{METHODS}

\section{Study design}

The authors performed a retrospective study of traumatic spine injury patients admitted to the Neurosurgery Institute of Cristo Redentor Hospital from January $1^{\text {st }}, 2013$ to December $31^{\text {st }}, 2018$. The study was approved by the Ethics in Research Committee of the hospital where it was conducted (CAAE: 75903717.3.0000.5530) under number 3.744.697. Since it is a retrospective study, for which data was collected without identification of the patients and without any impact on the treatment, the need for the patients to sign an informed consent form was dispensed with.

\section{Eligibility of patients}

The inclusion criteria were patients with traumatic spine injury. Patients admitted with spine infection disease (spondylodiscitis), degenerative spine cases, and pathological or osteoporotic fractures, were excluded.

\section{Variables analyzed}

The variables analyzed include demographic data (age, sex, race), information about the trauma (etiology, trauma mechanism, type of spine injury, number or vertebrae involved, vertebral segment involved), neurological status at hospital admission, the treatment performed (operative and non-operative) and the outcome (number of days in hospital, neurological outcome, and mortality). Neurological status at hospital admission and discharge was evaluated based on the Frankel scale. The outcome was analyzed based on mortality rate and the Frankel scale at hospital discharge. All variables were collected retrospectively from the hospital's computer records.
The spine segment injured was first classified as cervical, thoracic, thoracolumbar or lumbar. The cervical lesions were further stratified as C1, C2 or Cervical Subaxial Trauma (C3 to C7). Thoracic fractures from $\mathrm{T} 1$ to $\mathrm{T} 10$ were classified as Thoracic Spine Traumas. Fractures between T11 and L3 were classified as Thoracolumbar Spine Traumas. Fractures L3 to L5 were classified as Lumbar Spine Traumas.

Specific classifications were used to report the fractures according to the vertebrae affected. C1 fractures were reported according to the Jefferson classification as posterior arch, anterior arch, anterior and posterior arch, and lateral mass. ${ }^{24}$ Odontoid fractures were classified according to the Anderson and D'Alonzo classification. ${ }^{25}$ Fractures involving the articular pars of C2 were stratified based on the Levine and Edwards classifications. ${ }^{26}$ CT scans of Subaxial cervical, Thoracic, Thoracolumbar and Lumbar spine fractures were reviewed and classified using the AO Spine classification system. ${ }^{27,28}$

\section{Statistical analysis}

Data were collected using the software program Microsoft Excel 2019. The statistical analysis was performed using the Statistical Package for the Social Sciences (SPSS, version 22.0). The categorical variables were presented in proportion. The numerical variables were submitted to the Kolmogorov-Smirnov Test in order to evaluate their parametricity, and presented as mean and standard deviation if parametric, or median and interquartile range if non-parametric.

\section{RESULTS}

A total of 1329 patients with spine fractures were admitted between January $1^{\text {st }}, 2013$ and December $31^{\text {st }}, 2018$. Two hundred seventy-five patients with pathological fractures and 246 patients with osteoporotic fractures were excluded (Figure 1). The final number of patients included in the study was 808 (Figure 1).

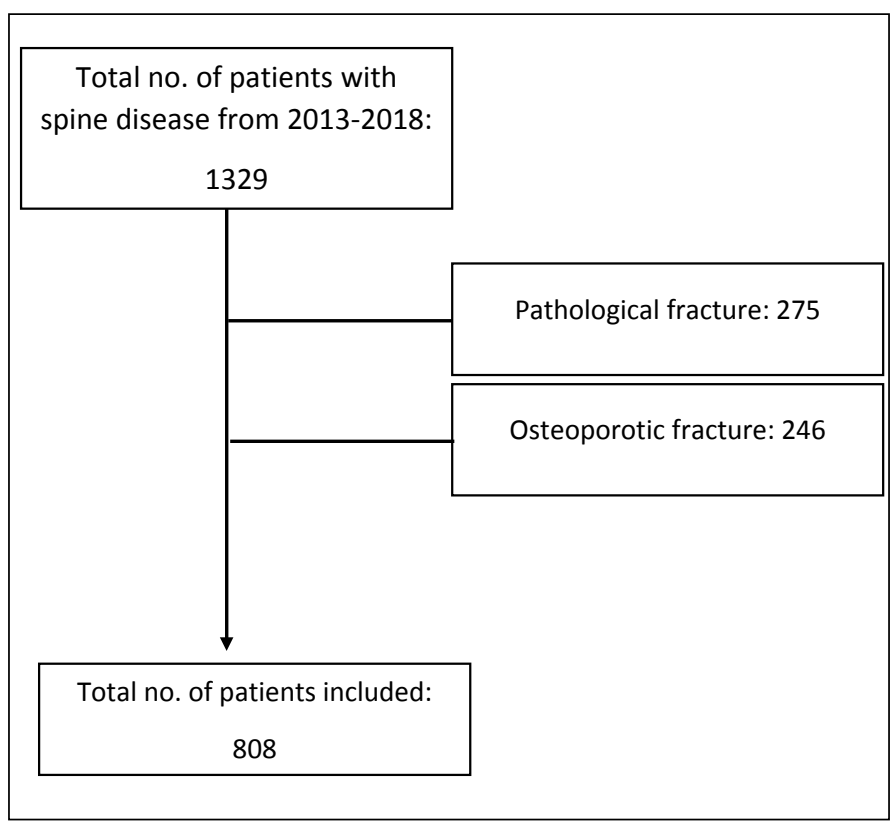

Figure 1. Patients included in the study. 


\section{Demographic data}

The mean age was $47.9( \pm 19.0)$. The majority of the cases were male $(66.3 \%)$ and Caucasian (90.7\%) (Table 1).

\section{Spine trauma etiology}

Fall from height ( $\mathrm{N}=508 ; 62.8 \%$ ) was the commonest cause of spine trauma, followed by traffic accident ( $\mathrm{N}=199 ; 24.6 \%)$ and violence $(\mathrm{N}=98 ; 12.1 \%)$. Among the cases of falls from height, 197 had fallen less than one meter and 311 more than one meter. Among the traffic accident cases, 105 were car accident casualties (13\%), 80 motorcycle accidents $(9.9 \%)$ and 14 bicycle accidents (1.7\%). The most frequent causes of violence were blunt trauma/aggression in 48 patients (5.9\%) and firearm in 45 patients (5.6\%). Sports spine injury was observed in only $3(0.4 \%)$ patients (Table 1 ).

\section{Spine trauma mechanism}

Spine fracture occurred in 731 (90.4\%) patients, vertebral dislocation occurred in $45(5.3 \%)$ and fracture associated with vertebral dislocation occurred in 34 (4.2\%). Multiple fractures were observed in 215 patients; these were further classified as cases of adjacent vertebrae fracture $(N=150 ; 70.0 \%)$ or fractures in different segments $(N=65 ; 30.0 \%)$.

Table 1. Epidemiological data

\begin{tabular}{|c|c|}
\hline Variable & Result \\
\hline Age & $47.9( \pm 19.0)^{\circ}$ \\
\hline Age $>65$ years & $167(20.7 \%)$ 은 \\
\hline \multicolumn{2}{|l|}{ Sex } \\
\hline Male & $536(66.3 \%)^{\circ}$ \\
\hline \multicolumn{2}{|l|}{ Race } \\
\hline White & $733(90.7 \%)^{\circ}$ \\
\hline Black & $53(6.6 \%)$ \\
\hline Indian & $22(2.7 \%) \cong$ \\
\hline \multicolumn{2}{|l|}{ Trauma Mechanism } \\
\hline Fall from height $(>1 \mathrm{~m})$ & $197(24.4 \%)^{\circ}$ \\
\hline Fall from height $(<1 \mathrm{~m})$ & $311(38.5 \%)$ 은 \\
\hline Motorcycle accident & $80(9.9 \%)$ \\
\hline Car accident & 105 (13\%)음 \\
\hline Firearm injury & $45(5.6 \%)^{\circ}$ \\
\hline Knife injury & $5(0.6 \%)$ 은 \\
\hline Blunt trauma/assault & 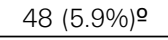 \\
\hline Bike & $14(1.7 \%)^{\circ}$ \\
\hline Sports & $3(0.4 \%)$ 은 \\
\hline \multicolumn{2}{|l|}{ Type of Spine Injury } \\
\hline Fracture & $731(90.4 \%)$ 은 \\
\hline Dislocation & $43(5.3 \%)^{\circ}$ \\
\hline Fracture-dislocation & $34(4.2 \%)^{\circ}$ \\
\hline Multiple Fractures & $215(26.6 \%)^{\circ}$ \\
\hline Surgical treatment & $298(36.9 \%)$ \\
\hline Conservative treatment & $510(63.1 \%)$ \\
\hline \multicolumn{2}{|l|}{ Level of vertebral fracture } \\
\hline $\mathrm{C} 1$ & $25(3.2 \%) \cong$ \\
\hline $\mathrm{C} 2$ & $67(8.7 \%) \cong$ \\
\hline $\mathrm{C} 3-\mathrm{C} 7$ & $94(12.2 \%)^{0}$ \\
\hline T1-T10 & $117(15.2 \%)^{\circ}$ \\
\hline T11-L2 & $401(52.1 \%)$ \\
\hline L3-L5 & $65(8.4 \%)^{\circ}$ \\
\hline Total days of hospitalization & $10(4-37.75)^{\underline{a}}$ \\
\hline Days in hospital before surgery & $9( \pm 8.14)^{*}$ \\
\hline Days in hospital after surgery & $5(3-12)^{\underline{a}}$ \\
\hline Days in hospital in surgical cases & $20(11-53.2)^{\underline{a}}$ \\
\hline Days in hospital in conservative cases & $5(3-20.2)^{a}$ \\
\hline Mortality & $15(1.9 \%)^{*}$ \\
\hline
\end{tabular}

\section{Spine level injury}

The thoracolumbar segment was the one most frequently affected, occurring in 401 (52.1\%) patients, followed by the cervical $(\mathrm{N}=186 ; 24.1 \%)$, thoracic $(\mathrm{N}=117 ; 15.2 \%)$ and lumbar $(\mathrm{N}=65 ; 8.4 \%)$ segments. The cervical spine fractures were located in $\mathrm{C} 1(\mathrm{~N}=25$; $3.2 \%)$, C2 ( $N=67 ; 8.7 \%)$, and subaxial ( $N=94 ; 12.2 \%$ ) (Figure 2).

\section{Treatment related data}

Operative treatment was performed in 298 (36.9\%) cases and non-operative treatment in 510 (63.1\%) patients. The most common non-operative treatment was the use of an orthosis. The median length of hospital stay was 10 (4-37.75) days. Among the operative patients, the median hospital stay was $20(11-.2), 9( \pm 8.14)$ before surgery and 5 (3-12) days after surgery. Among the non-operative patients, the median hospital stay was 5 (3-20.2) (Table 1).

\section{Neurological status and outcome}

The majority of the cases had normal neurological exam results at hospital admission (83.3\%). Complete spinal cord lesion was observed in 51 (6.3\%) patients. The cases of incomplete spinal cord injury were classified according to Frankel $\mathrm{B}(\mathrm{N}=9 ; 1.1 \%)$, Frankel $\mathrm{C}(\mathrm{N}=16 ; 2.0 \%)$, and Frankel $\mathrm{D}(\mathrm{N}=26 ; 3.2 \%)$.

The mortality rate was $1.9 \%$ (15 patients). Neurological status at hospital discharge demonstrated that 74 patients $(9.2 \%)$ were classified as Frankel A, 11 cases (1.4\%) as Frankel B, $13(1.6 \%)$ as Frankel C, 18 (2.2\%) as Frankel D, and $692(85.6 \%)$ as Frankel E, i.e. a normal neurological examination (Table 2).

\section{DISCUSSION}

The authors present the largest epidemiological study of patients with spine trauma performed in Latin America. Additionally, the authors evaluated the incidence and the characteristic of trauma according to different spine segments. The information presented here will fill a gap, because the epidemiological information was based on findings of European and North American countries, which do not necessarily have the same patient profile.

\section{Distribution by age and sex}

The present work showed that spine trauma mostly occurred in young males, corroborating previously published articles. ${ }^{7-9,12,29}$ A study published in the same state found similar distribution by age and sex. ${ }^{30} \mathrm{~A}$ progressive increase in rates of spine trauma was observed in patients aged over 65 years old; from $4.8 \%$ to $12.1 \% .{ }^{11}$ Our study reinforces this finding, as one fifth of the spine trauma patients in our study were older than 65 years.

\section{Trauma etiology}

A previous study reports that traffic accidents and violence, especially firearm injury, were the main spine trauma mechanisms in Brazil. ${ }^{31}$ Our study showed that fall from height was the main etiological mechanism, particularly from higher than 2 meters, which corroborates data from China, the USA and Spain. ${ }^{13,15,23,32}$ Traffic accidents were the second most frequent mechanism in our series, especially car accidents, which were also frequent in many other studies. ${ }^{21,32}$ Unlike Scandinavian studies, where there was a high percentage of spine trauma during sports practice, $, 2,21,22$ only 3 of the patients in our study had this trauma mechanism.

\section{Trauma mechanism}

Vertebral fracture was the most frequent injury after spine trauma. The incidence of patients with multiple fractures in this series is in accordance with the literature. ${ }^{5}$ We demonstrated that $70 \%$ of multiple fractures occurred in adjacent vertebrae and 30\% in distant vertebrae.

\section{Cervical spine trauma}

Cervical spine fractures are commonly classified according to the vertebrae involved, as the mechanism, neurological status, fracture 


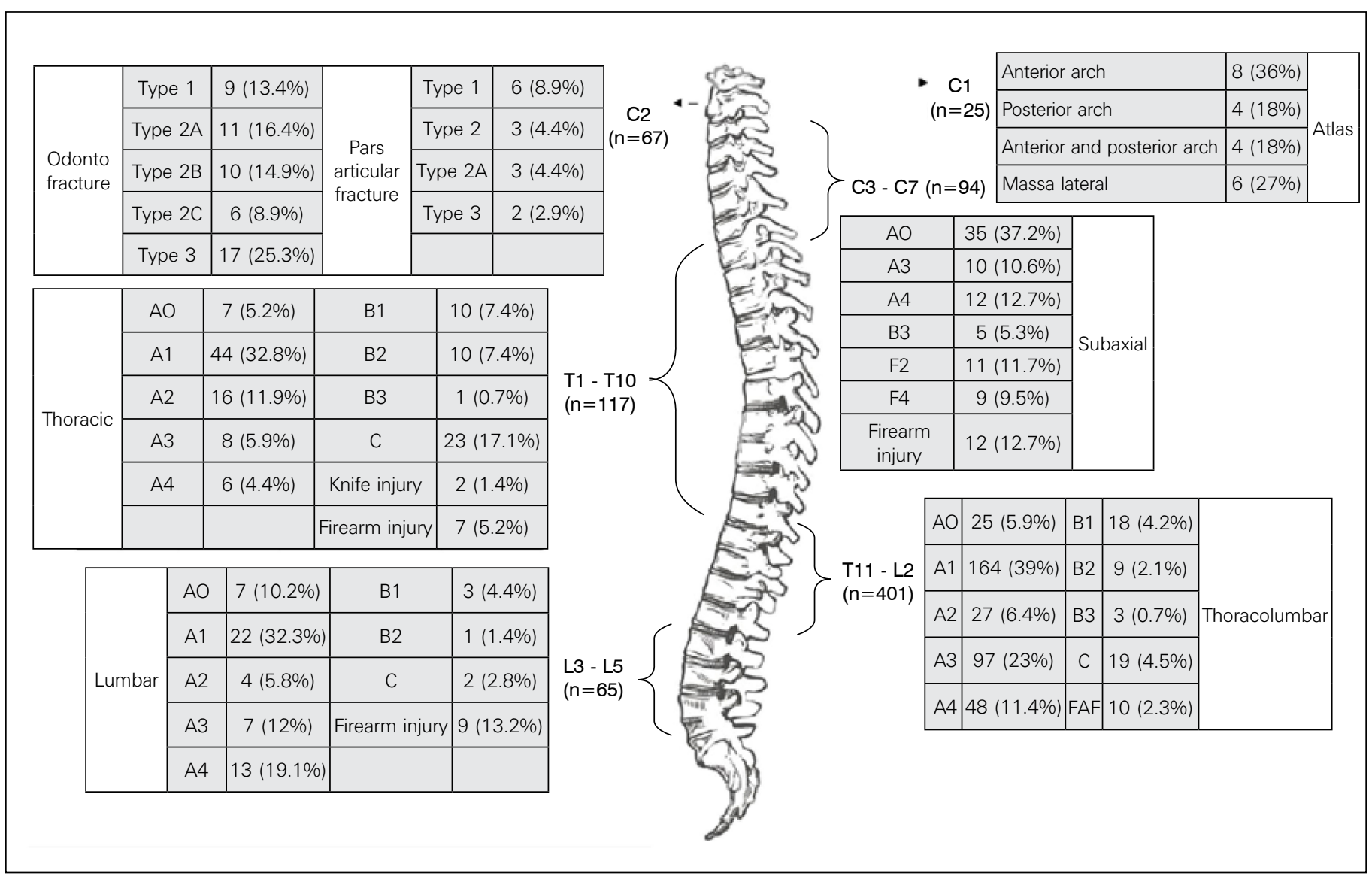

Figure 2. Fracture classification according to the vertebrae involved.

Table 2. Neurological status at hospital admission and discharge.

\begin{tabular}{c|c|c}
\hline Frankel Score & Hospital Admission & Hospital Discharge \\
\hline A & $80(9.9 \%)$ & $74(9.2 \%)$ \\
\hline B & $9(1.1 \%)$ & $11(1.4 \%)$ \\
\hline C & $16(2 \%)$ & $13(1.6 \%)$ \\
\hline$D$ & $26(3.2 \%)$ & $18(2.2 \%)$ \\
\hline E & $677(83.3 \%)$ & $692(85.6 \%)$ \\
\hline
\end{tabular}

classification and treatment are different. Our study showed that $13.4 \%$ of cervical fractures occurred in $\mathrm{C} 1$. In general, atlas $(\mathrm{C} 1)$ fractures represent $2 \%$ to $13 \%$ of all cervical spine injuries. ${ }^{33}$ Fractures of the second cervical vertebra (axis) comprise approximately one-third of cervical spine fractures, ${ }^{34}$ a percentage close to the $36 \%$ found in the present sample. The peculiar anatomy of the second cervical vertebra is different from that of all other levels, with the odontoid process and an elongated pars interarticularis between the atlantoaxial joint and the C2-C3 joint. For this reason, fracture of the axis is classified differently if it occurs at the odontoid process or the pars interarticularis. C2 fractures involved mainly the odontoid process in $79 \%$ of cases and the pars interarticularis in $21 \%$ of cases. Fifty percent of cervical fractures involved the subaxial segment, which corroborates the literature as the most common among cervical trauma. ${ }^{35}$

\section{Thoracic spine trauma}

The thoracic spine is functionally rigid due to coronally oriented facet joints, thin intervertebral discs and the ribcage. It requires great amounts of energy to produce fractures and dislocations. ${ }^{36}$ According to the literature, of the fractures involving the thoracic, thoracolumbar or lumbar segments, $25-40 \%$ occur in the thoracic segment. ${ }^{37}$ The present study found only $20 \%$ of fractures occurring in the thoracic segment (T1-T10).

\section{Thoracolumbar spine trauma}

The thoracolumbar junction (T10-L2) is uniquely positioned between the rigid thoracic spine and the mobile lumbar spine. This transition from the less mobile thoracic spine, with its associated ribs and sternum, to the more dynamic lumbar spine results in the thoracolumbar region being subjected to significant biomechanical stress. ${ }^{37}$ Fractures of the thoracolumbar region are the most common injuries of the vertebral column. ${ }^{36}$ Our study showed that fractures between T11-L2 occurred in $52.1 \%$ of the whole sample, and $68.7 \%$ of the cases when cervical segment was excluded.

\section{Lumbar spine trauma}

The lumbar spine is flexible due to the thicker intervertebral discs, sagittal orientation of the facet joints and the absence of the rib cage. The lumbar segment is not frequently involved in spine trauma, representing $10-14 \%$ of cases, according to the literature, ${ }^{37}$ a range that corroborates the $11.14 \%$ found in this sample.

\section{Neurological status}

Approximately, 15 to $20 \%$ of patients with spinal trauma have associated neurological damage. ${ }^{38}$ Based on our study, $17 \%$ of patients have neurological impairment. Most of them have complete $\mathrm{SCl}$. Different findings were described in a study published previously, in the same city. ${ }^{30}$

\section{Treatment and outcome}

Operative therapy was performed in $40 \%$ of the patients, which demonstrated the high proportion of severe cases in our sample. However, the mortality rate of $2 \%$ was low. A greater number of patients had normal neurological function at hospital discharge or improved neurologic function, when compared with their status at admission. 


\section{Strengths and Limitations}

The main strengths of this study are the large sample size and the fact that several variables are analyzed, allowing a broad evaluation of different aspects of the pathology, radiology, and patients. This allows an overall understanding of the importance of each variable in the scenario of the spine trauma patient. Some limitations must also be recognized, particularly the fact that this study uses only retrospective data. Despite the retrospective study design, all the variables analyzed were successfully retrieved from the hospital digital system. The results came from experience at a single center, which may represent a selection bias, as it is located within a tertiary hospital. Therefore, minor traumas or fractures may not have been referred to this service, or may have been discharged from the emergency room for treatment at the primary care level.

\section{CONCLUSION}

Adult males are the subgroup at higher risk of spine trauma, especially as a result of falls and traffic accidents. The thoracolumbar segment is the one most involved and, in accordance with the other segments, the majority of patients have stable fractures without neurological involvement.

\section{ACKNOWLEDGEMENTS}

\section{AO Spine Latin America}

All authors declare no potential conflict of interest related to this article.

CONTRIBUTION OF THE AUTHORS: Each author made significant individual contributions to this manuscript. GF: conceptualization, methodology, formal analysis, investigation, resources, data curation, writing the original draft, reviewing and editing the final version, and project administration. MECG, TPBC: conceptualization, methodology, investigation, resources, reviewing and editing the final version. TLN: investigation, resources, writing the original draft, reviewing and editing the final version. FMLC, ES: formal analysis, investigation, and writing the original draft. AMLC: conceptualization, formal analysis, investigation, and writing the original draft. AF: conceptualization, methodology, writing the original draft, reviewing and editing the final version, and project administration.

\section{REFERENCES}

1. Brito LMO, Chein MB da C, Marinho SC, Duarte TB. Epidemiological evaluation of victims of spinal cord injury. Rev Col Bras Cir. 2011;38(5):304-9. doi: 10.1590/S010069912011000500004

2. Campos MF De, Ribeiro AT, Listik S, Pereira CADB, Sobrinho JDA, Rapoport A. Epidemiologia do traumatismo da coluna vertebral. Rev Col Bras Cir. 2008;35(2):88-93. doi: 10.1590/ S0100-69912008000200005

3. Cerezetti CRN, Nunes GR, Cordeiro DRCL, Tedesco S. Lesão Medular Traumática e estratégias de enfrentamento: Revisão crítica. Mundo da Saúde. 2012;36(2):318-26.

4. Dryden DM, Saunders LD, Rowe BH, May LA, Yiannakoulias N. Svenson LW, et al. Depression following traumatic spinal cord injury. Neuroepidemiology. 2005;25(2):55-61. doi: $10.1159 / 000086284$

5. Ropper $A E$, Ropper $\mathrm{AH}$. Acute Spinal Cord Compression. N Engl J Med. 2017;376(14):1358-69. doi: 10.1056/NEJMra1516539.

6. Rouanet C, Reges D, Rocha E, Gagliardi V, Silva GS. Traumatic spinal cord injury: current concepts and treatment update. Arq Neuropsiquiatr. 2017;75(6):387-93. doi: 10.1590/0004-282x20170048.

7. Botelho RV, Gianini Albuquerque LD, Junior RB, Arantes Júnior AA. Epidemiology of traumatic spinal injuries in Brazil: systematic review. Arq Bras Neurocir Brazilian Neurosurg. 2014;33(02):100-6. Doi:10.1055/s-0038-1626255.

8. Do Nascimento TL, Rogério LPW, Dos Reis MM, De Almeida LP, Finger G, Greggianin $\mathrm{GF}$, et al. Thoracolumbar spinal arthrodesis -epidemiology and costs. Coluna/Columna. 2017;16(1):52-55. doi: 10.1590/s1808-185120171601162774.

9. Koskinen EA, Alen M, Väärälä EM, Rellman J, Kallinen M, Vainionpää A. Centralized spinal cord injury care in Finland: unveiling the hidden incidence of traumatic injuries. Spinal Cord. 2014;52(10):779-84. doi: 10.1038/sc.2014.131.

10. Rahimi-Movaghar V, Sayyah MK, Akbari H, Khorramirouz R, Rasouli MR, Moradi-Lakeh M, et al. Epidemiology of traumatic spinal cord injury in developing countries: A systematic review. Neuroepidemiology. 2013;41(2):65-85. doi: 10.1159/000350710.

11. Van Den Berg MEL, Castellote JM, Mahillo-Fernandez I, De Pedro-Cuesta J. Incidence of spinal cord injury worldwide: A systematic review. Neuroepidemiology. 2010;34(3):184-92; discussion 192. doi: 10.1159/000279335

12. Ning GZ, Yu TQ, Feng SQ, Zhou XH, Ban DX, Liu Y, et al. Epidemiology of traumatic spinal cord injury in Tianjin, China. Spinal Cord. 2011;49(3):386-90. doi: 10.1038/sc.2010.130.

13. Lee BB, Cripps RA, Fitzharris M, Wing PC. The global map for traumatic spinal cord injury epidemiology: Update 2011, global incidence rate. Spinal Cord. 2014;52(2):110-6. doi: 10.1038/sc.2012.158.

14. Robert AA, Zamzami MM. Traumatic spinal cord injury in Saudi Arabia: A review of the literature. Pan Afr Med J. 2013;16:1-6. doi: 10.11604/pamj.2013.16.104.2902

15. Zhou Y, Wang XB, Kan SL, Ning GZ, Li YL, Yang B, et al. Traumatic spinal cord injury in Tianjin, China: A single-center report of 354 cases. Spinal Cord. 2016;54(9):6704. doi: 10.1038/sc.2015.173.

16. Wyndaele M, Wyndaele JJ. Incidence, prevalence and epidemiology of spinal cord injury: What learns a worldwide literature survey? Spinal Cord. 2006;44(9):523-9. doi: 10.1038/ sj.sc.3101893.

17. Furlan JC, Sakakibara BM, Miller WC, Krassioukov AV. Global Incidence and Prevalence of Traumatic Spinal Cord Injury. Can J Neurol Sci. 2013:40(4):456-64. doi: 10.1017/ s0317167100014530.

18. Jain NB, Ayers GD, Peterson EN, Harris MB, Morse L, O'Connor KC, et al. Traumatic spinal cord injury in the United States, 1993-2012. JAMA. 2015;313(22):2236-43. doi: 10.1001/ jama.2015.6250

19. Aito S, Tucci L, Zidarich V, Werhagen L. Traumatic spinal cord injuries: Evidence from 30 years in a single centre. Spinal Cord. 2014;52(4):268-71. doi: 10.1038/sc.2014.2

20. Bárbara-Bataller E, Méndez-Suárez JL, Alemán-Sánchez C, Sánchez-Enríquez J, SosaHenríquez M. Change in the profile of traumatic spinal cord injury over 15 years in
Spain. Scand J Trauma Resusc Emerg Med. 2018;26(1):1-8. doi: 10.1186/s13049018-0491-4.

21. Bjørnshave Noe B, Mikkelsen EM, Hansen RM, Thygesen M, Hagen EM. Incidence of traumatic spinal cord injury in Denmark, 1990-2012: A hospital-based study. Spinal Cord. 2015;53(6):436-40. doi: 10.1038/sc.2014.181.

22. Halvorsen A, Pettersen AL, Nilsen SM, Halle KK, Schaanning EE, Rekand T. Epidemiology of traumatic spinal cord injury in Norway in 2012-2016: a registry-based cross-sectional study. Spinal Cord. 2019;57(4):331-8. doi: 10.1038/s41393-0180225-5.

23. Montoto-Marqués A, Ferreiro-Velasco ME, Salvador-De La Barrera S, Balboa-Barreiro V, Rodriguez-Sotillo A, Meijide-Failde R. Epidemiology of traumatic spinal cord injury in Galicia, Spain: Trends over a 20-year period. Spinal Cord. 2017;55(6):588-94. doi: $10.1038 /$ sc. 2017.13

24. Mead LB, Millhouse PW, Krystal J, Vaccaro AR. C1 fractures: a review of diagnoses, management options, and outcomes. Curr Rev Musculoskelet Med. 2016;9(3):25562. doi: 10.1007/s12178-016-9356-5.

25. Anderson LD, D'Alonzo RT. Fractures of the odontoid process of the axis. J Bone Joint Surg Am. 1974;56(8):1663-74.

26. Levine AM, Edwards CC. The management of traumatic spondylolisthesis of the axis. J Bone Joint Surg Am. 1985;67(2):217-26.

27. Divi SN, Schroeder GD, Oner FC, Kandziora F, Schnake KJ, Dvorak MF, et al. AOSpine - Spine Trauma Classification System: The Value of Modifiers: A Narrative Review With Commentary on Evolving Descriptive Principles. Global Spine J. 2019;9(1 Suppl):77S-88S. doi: 10.1177/2192568219827260.

28. Vaccaro AR, Oner C, Kepler CK, Dvorak M, Schnake K, Bellabarba C, et al. AOSpine thoracolumbar spine injury classification system: Fracture description, neurological status, and key modifiers. Spine (Phila Pa 1976). 2013;38(23):2028-37. doi: 10.1097/ BRS.0b013e3182a8a381.

29. Hamid R, Averbeck MA, Chiang H, Garcia A, Al Mousa RT, Oh SJ, et al. Epidemiology and pathophysiology of neurogenic bladder after spinal cord injury. World J Urol. 2018;36(10):1517-27. doi: 10.1007/s00345-018-2301-z.

30. Frison VB, Teixeira G de O, Oliveira TF de, Resende T de L, Netto CA. Estudo do perfil do trauma raquimedular em Porto Alegre. Fisioter e Pesqui. 2013;20(2):165-71. doi: 10.1590/ S1809-29502013000200011

31. Da Silva OT, Ghizoni $E$, Tedeschi $H$, Joaquim AF. Epidemiology of spinal trauma surgically treated at the unicamp hospital das clínicas. Coluna/ Columna. 2018;17(1):558. doi: 10.1590/s1808-185120181701179262.

32. Selassie A, Cao Y, Saunders LL. Epidemiology of Traumatic Spinal Cord Injury Among Persons Older Than 21 Years: A Population-Based Study in South Carolina, 1998-2012. Top Spinal Cord Inj Rehabil. 2015;21(4):333-44. doi: 10.1310/sci2104-333.

33. Kakarla UK, Chang SW, Theodore N, Sonntag VKH. Atlas fractures. Neurosurgery. 2010;66(3 Suppl):60-7. doi: 10.1227/01.NEU.0000366108.02499.8F

34. Gornet ME, Kelly MP. Fractures of the axis: a review of pediatric, adult, and geriatric injuries. Curr Rev Musculoskelet Med. 2016;9(4):505-12. doi: 10.1007/s12178-016-9368-1.

35. Feuchtbaum E, Buchowski J, Zebala L. Subaxial cervical spine trauma. Curr Rev Musculoskelet Med. 2016;9(4):496-504. doi: 10.1007/s12178-016-9377-0

36. Rajasekaran S, Kanna RM, Shetty AP. Management of thoracolumbar spine trauma An overview. Indian J Orthop. 2015:49(1):72-82. doi: 10.4103/0019-5413.143914

37. Wood KB, Li W, Lebl DS, Ploumis A. Management of thoracolumbar spine fractures. Spine J. 2014;14(1):145-64. doi: 10.1016/j.spinee.2012.10.041.

38. Haimoto S, Schär RT, Nishimura Y, Hara M, Wakabayashi T, Ginsberg HJ. Reduction in surgical site infection with suprafascial intrawound application of vancomycin powder in instrumented posterior spinal fusion: A retrospective case-control study. $J$ Neurosurg Spine. 2018;29(2):193-8. doi: 10.3171/2017.12.SPINE17997. 